Gut, 1984, 25, 174-177

\title{
Interaction of calcium and gastrin on gastric acid secretion in duodenal ulcer patients
}

\author{
J CHRISTIANSEN, P KIRKEGAARD, P S OLSEN, AND B PETERSEN
}

From the Department of Surgery D, Glostrup Hospital, University of Copenhagen, Copenhagen, Denmark

SUMmARY A dose response study of the effect on gastric acid secretion of synthetic human gastrin-17 in doses of 50,200 , and $500 \mathrm{ng} / \mathrm{kg} / \mathrm{h}$ was performed in eight healthy volunteers and in eight patients with duodenal ulcer. The study was repeated on a separate day during intravenous infusion of calcium gluconate $\left(0 \cdot 1 \mathrm{mmol} \mathrm{Ca}{ }^{2+} / \mathrm{kg} / \mathrm{h}\right)$. In healthy subjects the acid response to the combined infusion of synthetic human gastrin and calcium did not significantly exceed the response to synthetic human gastrin alone, in contrast with patients with duodenal ulcer in whom the combined infusion did significantly improve acid output compared with infusion of synthetic human gastrin alone. The dose of synthetic human gastrin required for half maximal acid response $\left(D_{50}\right)$ was reduced in both groups but significantly more in patients with duodenal ulcer. No difference in serum gastrin concentrations or in serum calcium concentrations were found. It is hypothesised that extracellular calcium plays a role in gastrin stimulated acid secretion in man and that patients with duodenal ulcer are more sensitive to this calcium dependent mechanism than non-duodenal ulcer subjects.

Calcium may participate in the stimulation of gastric acid secretion in man by a dual mechanism - that is, by gastrin release ${ }^{12}$ and by an action directly on the parietal cell. ${ }^{13}$

In previous studies it was found that calcium increases the sensitivity of the parietal cells to synthetic human gastrin in healthy subjects. ${ }^{3}$ Furthermore, that administration of verapamil decreases the sensitivity of the parietal cells to gastrin, suggesting that influx of calcium into the parietal cells is an essential step in the acid secretory process. $^{4}$

The aim of the present study has been to investigate whether calcium dependence of the parietal cells is quantitatively different in normal subjects and patients with duodenal ulcer.

\section{Methods}

\section{SUBJECTS}

Nine healthy volunteers (five men and four women, aged 21-38 years) and nine patients with duodenal ulcer (six men and three women, aged $26-48$ years) were studied. Each subject was studied twice on separate days. All gave informed consent.

Address for correspondence: John Christiansen, MD, Department of Surgery D. Glostrup Hospital, DK-2600 Copenhagen, Denmark.

Received for publication 6 May 1983
EXPERIMENTAL PROCEDURE

On the first day, synthetic human gastrin-17 (SHG, Imperial Chemical Industries, Cheshire, England) was infused. After an overnight fast, a Levin tube was placed in the stomach under fluoroscopic control. Intermittent mechanical suction producing a subatmospheric pressure of $150 \mathrm{mmHg}$ was used in the collection of the secretion. Through a thin polyvinyl tube welded to the Levin tube, a marker substance was instilled into the stomach $\left({ }^{51} \mathrm{Cr}\right.$ EDTA, flow $30 \mathrm{ml} / \mathrm{h}$ ) to determine recovery. The opening in the polyvinyl tube was $10 \mathrm{~cm}$ proximal to the most proximal opening in the Levin tube. The volume of secretion collected was measured for each 15 minute period, and the concentration of $\mathrm{H}^{+}$and ${ }^{51} \mathrm{Cr}$-EDTA determined. Synthetic human gastrin was administered by continuous intravenous infusion in doses of 50,200 , and $500 \mathrm{ng} / \mathrm{kg} / \mathrm{h}$; each dose was adminisiered for one hour.

On the second day, the experiment was repeated on a background infusion of calcium gluconate $(0 \cdot 1$ $\mathrm{mmol} \mathrm{Ca} / \mathrm{kg} / \mathrm{h}$ ). Infusion of calcium started one hour before the infusion of synthetic human gastrin and continued throughout the experiment - that is, for four hours. Calcium gluconate for infusion was prepared by the hospital's pharmaceutical department in a concentration of $0.66 \mathrm{mmol} / \mathrm{ml}$ of $\mathrm{Ca}^{2+}$. For further dilution, $0.9 \%$ saline was used. 
LABORATORY ANALYSIS

The concentration of $\mathrm{H}^{+}$was determined by titration with an autotitrator (Radiometer, Copenhagen) to $\mathrm{pH} 7 \cdot 0$. The concentration of ${ }^{51} \mathrm{Cr}$-EDTA was determined in a well counter. The volume of the secretion and the output of $\mathrm{H}^{+}$were corrected to the actual recovery by the marker substance instilled. Repeated estimations of osmolarity by freezing point reduction were taken as an index of the degree of duodenal reflux. ${ }^{5}$ Serum calcium concentration was determined by atomic absorption spectrophotometry and serum gastrin concentration was measured radioimmunochemically. ${ }^{6}$

\section{CALCULATIONS}

Correction for non-recovered gastric juice was done for every 15 minute sample according to the formula:

$$
\mathrm{V}_{\text {cor }}=\mathrm{V}_{\text {asp }} \times \mathrm{C}_{\text {inf }} / \mathrm{C}_{\text {asp }}
$$

where $V_{\text {cor }}$ is the corrected volume, $V_{\text {asp }}$ the aspirated volume, $C_{\text {inf }}$ the number of 'counts' infused, and $\mathrm{C}_{\text {asp }}$ the number of counts aspirated.

In the calculations acid output in the last two 15 minute periods of each synthetic human gastrin dose was used.

The dose of synthetic human gastrin required for one-half maximal acid secretion $\left(D_{50}\right)$ and the calculated maximal response were calculated by linear transformation of the Michaelis-Menten equation according to Dowd-Riggs:

$$
\mathrm{V}=\mathrm{CMR}-\mathrm{D}_{50}(\mathrm{v} / \mathrm{d})
$$

where $v$ is acid response and $d$, the dose of synthetic human gastrin administered. These calculations were performed on the individual data by computerised estimation of the regression line according to the method of least squares. For the statistical analysis, paired $t$ test and the coefficient of correlation ( $r$ ) were used. Values of $p<0.05$ were considered significant.

\section{Results}

Acid secretion in the control subjects is shown in Fig. 1 and in patients with duodenal ulcer in Fig. 2 . In healthy subjects calcium increased the acid response to the lowest dose of synthetic human gastrin $(50 \mathrm{ng} / \mathrm{kg} / \mathrm{h})$ significantly, whereas the integrated acid output over the total dose range of synthetic human gastrin was not significantly increased. This is in contrast with findings in duodenal ulcer patients where calcium significantly increased the integrated acid output to synthetic human gastrin.

Calculated maximal response and $D_{50}$ are shown in Table 1. No significant difference was found

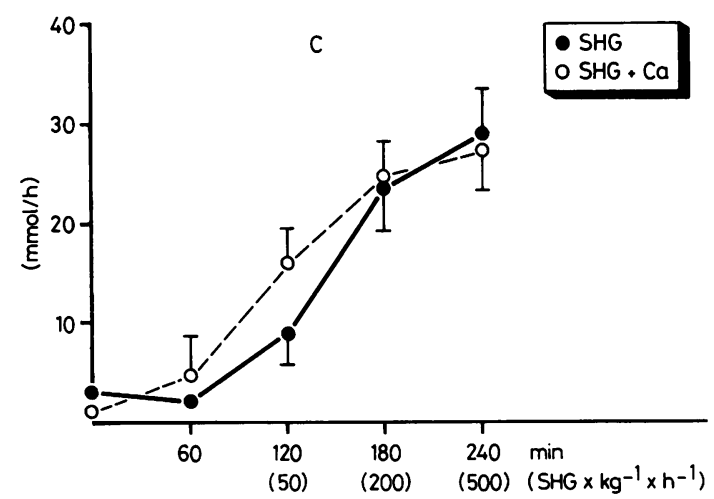

Fig. 1 Gastric acid secretion in eight healthy subjects during infusion of increasing doses of synthetic human gastrin and during infusion of synthetic human gastrin + calcium.

between control subjects and patients with duodenal ulcer. Calcium infusion did not alter calculated maximal response in healthy subjects, whereas calculated maximal response was non-significantly increased in patients with duodenal ulcer. $\mathrm{D}_{50}$ was reduced significantly in both groups, $55 \%$ in patients with duodenal ulcer and $29 \%$ in the control group. Reduction of $D_{50}$ was significantly greater in the patients than in the control subjects.

Serum gastrin concentrations are shown in Table 2. No difference was found between patients and control subjects. This' is true also for serum calcium concentration (Table 3).

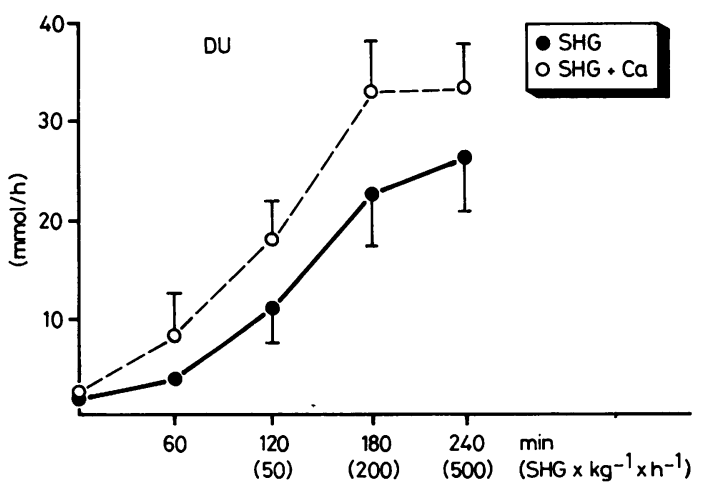

Fig. 2 Gastric acid secretion in eight duodenal ulcer patients during infusion of increasing doses of synthetic human gastrin and during infusion of synthetic human gastrin + calcium. 
Table 1 Calculated maximal response $\left(\mathrm{mmol} \mathrm{H}^{+} / \mathrm{h}\right)$ and

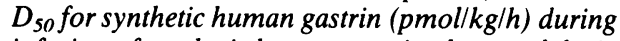
infusion of synthetic human gastrin alone and during infusion of synthetic human gastrin + calcium

\begin{tabular}{|c|c|c|c|c|}
\hline & \multicolumn{2}{|l|}{$D_{50}$} & \multicolumn{2}{|c|}{$\begin{array}{l}\text { Calculated } \\
\text { maximal response }\end{array}$} \\
\hline & $C$ & $D U$ & $C$ & $D U$ \\
\hline \multirow{2}{*}{$\begin{array}{l}\text { Synthetic human gastrin } \\
\text { Synthetic human gastrin } \\
+ \text { calcium }\end{array}$} & 138 & 129 & $34 \cdot 2$ & $33 \cdot 8$ \\
\hline & 98 & 58 & $36 \cdot 5$ & $40 \cdot 3$ \\
\hline
\end{tabular}

Table 2 Serum gastrin concentrations (pmol/l) in duodenal ulcer patients $(D U)$ and control subjects $(C)$ during infusion of synthetic human gastrin and during infusion of synthetic human gastrin + calcium

\begin{tabular}{|c|c|c|c|c|c|}
\hline & & \multicolumn{4}{|c|}{$\begin{array}{l}\text { Dose of synthetic human gastrin } \\
(\mathrm{pmol} / \mathrm{kg} / \mathrm{h})\end{array}$} \\
\hline & & 0 & 25 & 100 & 250 \\
\hline $\begin{array}{c}\text { - Calcium } \\
\text { infusion }\end{array}$ & $\begin{array}{l}\text { DU } \\
\text { C }\end{array}$ & $\begin{array}{l}18 \pm 2 \\
16 \pm 2\end{array}$ & $\begin{array}{l}44 \pm 3 \\
46 \pm 4\end{array}$ & $\begin{array}{l}248 \pm 75 \\
215 \pm 65\end{array}$ & $\begin{array}{l}580 \pm 100 \\
520 \pm 90\end{array}$ \\
\hline infusion & $\begin{array}{l}\text { DU } \\
\text { C }\end{array}$ & $\begin{array}{l}20 \pm 2 \\
19 \pm 2\end{array}$ & $\begin{array}{l}52 \pm 4 \\
49 \pm 3\end{array}$ & $\begin{array}{l}235 \pm 55 \\
200 \pm 50\end{array}$ & $\begin{array}{l}525 \pm 80 \\
535 \pm 90\end{array}$ \\
\hline
\end{tabular}

Table 3 Serum calcium concentration (mmol/l) in duodenal ulcer patients $(D U)$ and control subjects $(C)$ during infusion of synthetic human gastrin and during infusion of synthetic human gastrin + calcium

\begin{tabular}{|c|c|c|c|c|c|}
\hline & \multicolumn{5}{|c|}{ Dose of synthetic human gastrin ( $\mathrm{pmol} / \mathrm{kg} / \mathrm{h})$} \\
\hline & & 0 & 25 & 100 & 250 \\
\hline \multirow[t]{2}{*}{ - Calcium infusion } & DU & $2 \cdot 35 \pm 0.06$ & $2 \cdot 39 \pm 0.08$ & $2 \cdot 32 \pm 0 \cdot 06$ & $2.33 \pm 0.09$ \\
\hline & $\mathrm{C}$ & $2 \cdot 34 \pm 0.04$ & $2 \cdot 40 \pm 0.04$ & $2 \cdot 40 \pm 0.05$ & $2 \cdot 38 \pm 0.06$ \\
\hline \multirow[t]{2}{*}{+ Calcium infusion } & DU & $2 \cdot 34 \pm 0.04$ & $2 \cdot 58 \pm 0.02$ & $2 \cdot 65 \pm 0.06$ & $2 \cdot 81 \pm 0 \cdot 11$ \\
\hline & $\mathrm{C}$ & $2 \cdot 47 \pm 0.03$ & $2.63 \pm 0.07$ & $2 \cdot 71 \pm 0.05$ & $2 \cdot 82 \pm 0.08$ \\
\hline
\end{tabular}

\section{Discussion}

It is well documented that calcium is able to induce gastric acid secretion in man. ${ }^{7}$ One mechanism is by release of antral gastrin, ${ }^{128}$ where transport of calcium over the cellular membrane seems to play a role in the stimulus-secretion coupling in the gastrin cell. ${ }^{2}$ Another mechanism by which calcium may stimulate acid secretion is by a direct effect on the parietal cell where transmembrane influx seems to be an essential step as suggested by previous studies on the effect of calcium antagonists. ${ }^{34}$

In gastrin stimulated acid secretion calcium flux across the cell membrane or alteration of membrane calcium may be part of a second effector system, ${ }^{9} \mathrm{a}$ concept which is indirectly supported by our previous studies. ${ }^{34}$ If this is true the increased sensitivity could be due to an increased sensitivity to calcium or to facilitated influx of calcium into the parietal cell. The present study shows that the same amount of calcium administered to healthy subjects and to patients with duodenal ulcer, significantly increased the acid response to synthetic human gastrin and reduced $D_{50}$ in the patients.

This finding, as well as previous studies ${ }^{34}$ support, although indirectly, the view that influx of calcium across or into the cell membrane plays a role for gastrin stimulated acid secretion, and furthermore that patients with duodenal ulcer are more sensitive to this mechanism than healthy subjects.

\section{References}

1 Christiansen J, Rehfeld JF, Stadil F. Interaction of calcium and magnesium in gastric acid secretion and serum gastrin concentration in man. Gastroenterology 1975; 68: 1140-3.

2 Harty RF, Maico DG, McGuigan JE. Role of calcium in antral gastrin release. Gastroenterology 1981; 80: 491-7.

3 Christiansen J, Rehfeld JF, Kirkegaard P. Interaction of calcium, magnesium and gastrin on gastric acid secretion. Gastroenterology 1979; 76: 57-61.

4 Kirkegaard P, Christiansen J, Petersen B, Olsen PS. Calcium and stimulus secretion coupling in gastric fundic mucosa. Scand J Gastroenterol 1982; 17: 533-8.

5 Henriksen FW, Jörgensen SP, Möller S. Interaction between secretin and cholecystokinin on inhibition of gastric secretion in man. Scand J Gastroenterol 1974; 9: 735-40.

6 Satdil F, Rehfeld JF. Radioimmunoassay of gastrin in human serum. Scand J Gastroenterol 1971; 6: suppl: $61-5$. 
7 Reeder JJ, Jackson BM, Ben J et al. Influence of hypercalcaemia on gastric secretion and serum gastrin concentration in man. Ann Surg 1970; 172: 540-6.

8 Christiansen J, Rehfeld JF, Stadil F. The effect of calcium on gastric acid and gastrin secretion in antrectomized subjects. Gut 1974; 15: 622-5.
9 Soll AH, Walsh JH. Regulation of gastric acid secretion. Ann Rev Physiol 1979; 4: 35-53.

10 Isenberg JI, Grossmann MI, Maxwell V, Walsh JH. Increased sensitivity to stimulation of acid secretion by pentagastrin in duodenal ulcer. J Clin Invest 1975; 55: $330-7$. 